\begin{tabular}{lcc}
\hline \multicolumn{1}{c}{ A N N A L E S } \\
UNIVERSITATIS MARIAE CURIE-SKŁODOWSKA \\
LUBLIN - POLONIA \\
SOL. XXVII, 2 & SECTIOK \\
\hline
\end{tabular}

Reviews. Reports

Recenzje. Sprawozdania

JUSTYNA BRĄCZYK

\title{
Review of: Krzysztof Korzeniowski, Psychologia demokracji. Szkice [Psychology of Democracy. Sketches], Wydawnictwo Naukowe PWN, Warszawa 2020, pp. 230
}

Nowadays, the vast majority of Poles can be considered supporters of democracy, as many of them believe that it is the best possible form of the political system [CBOS 2014: 4-8]. The Constitution of the Republic of Poland from 1997, in its basic principles, places Poland quite precisely among liberal democracies [Ossowski 2008: 101]. However, the analysis of various world rankings indicates that recent years have brought a democratic crisis that can be observed both in Poland and in the world. The reviewed book by Krzysztof Korzeniowski, entitled Psychologia demokracji. Szkice [Psychology of Democracy. Sketches] poses to the reader the following questions: Does the current political situation in Poland still bear the features of the democracy we support so much or is it only an empty name that is left? Do Poles have a good understanding of their ruling system and its basic assumptions? How do the mentality, conspiratorial thinking and undeniably high religiosity of Polish people affect their current support for democracy? The author provides us with answers to these and other questions, drawing on the results of his many years of empirical research.

Professor Krzysztof Korzeniowski is a social psychologist currently working at the Institute of Psychology of the Polish Academy of Sciences. His research interests include macropsychology, systemic transformation, religiosity, social identity, and more. He is known for his extensive empirical activity as a manager and participant of many research grants. 
The book consists of two main parts. The first one is an extensive introduction to the subject of the work, focusing on familiarizing the reader with the concept of democracy, how it can be understood and how many colors and forms it takes. It also shows what democracy is not and what political system could be its opposite. Apart from a purely semantic and conceptual introduction, this part also provides the current socio-political context, describing the current state of democracy in Poland and in the world.

The second, much more extensive part, presents the results of the author's empirical research. They were carried out as part of three large nationwide research projects conducted in 2002, 2010 and 2017. Their subject matter largely coincides, which makes it possible to track changes in time in terms of the main phenomena discussed in the book, i.e. support for democracy, authoritarianism, conspirational thinking, political paranoia, political bewilderment and religiosity. A separate chapter, in which a very detailed description of a given phenomenon is presented from various theoretical approaches, is devoted to each of them. Subsequently, each phenomenon is transferred to the Polish ground and then, the results are presented in the form of correlation tables or path analysis models. Interestingly, the book comes with a several-page appendix titled "A quick guide to statistics and methodology of social research (issues covered in this book)". As the author himself writes, the guide was created "for the readers less familiar with the nuances of inductive statistics" [p. 221] and its aim is to introduce terms that will help in understanding the statistical methods and formulas used in the book.

I found the arrangement of the book pleasantly structured and undoubtedly accessible to every reader. Before presenting the results of his research, the author took care of broad preparation of the reader from the theoretical point of view, and familiarization with the impressive pantheon of the other researchers' work. Readers who are less familiar with the methodology of social research have certainly benefited from the statistical guide at the end of the book. The research results themselves have been described in a clear and accessible way and have been summarized accordingly - thanks to that, even a layman will understand the social problems raised.

The main goal of the reading was to empirically test the path model, in which the exogenous factors were religiosity and failure to respect the principle of reality (also understood as delusional thinking) and the main variable explained was support for democracy. Authoritarianism and political paranoia acted as mediators. An enlightened understanding of democracy appeared as a mediator in the model built on data collected in 2010, and as an additional variable explained in the model on data collected in 2017.

From a methodological point of view, the model seems to have a proper theoretical justification. The absolute fit index of the model indicates a very good compatibility with empirical data. However, the question arises of whether presented model is exhaustive. It would probably be constructive to expand it with additional variables, especially since the author himself emphasizes that paranoia is probably 
strongly influenced by other factors, not included in the model. However, this is not a serious objection as the author gives us probable explanations for this state of affairs.

Korzeniowski, analyzing the results obtained in the model based on the 2017 data, points out the great meaning of religiosity. Strong religious beliefs greatly weakened support for democracy, both directly and through authoritarianism. It had a negative effect on an enlightened understanding of democracy, but also on political paranoia, which, in turn, revealed the democracy promoting properties. This result, although extremely interesting, raises the question of whether in a country as religious as Poland, true and liberal democracy has a raison d'être. The author provides comprehensive and reliable explanations on this subject as well. He suspects that Catholicism and modern democracy are so difficult to reconcile due to the strict centralization and hierarchization of the structure of the Catholic Church in Poland. Citizens socialized in this way, accustomed to being divided into better and worse, may show a distrust of more equal structures. As a result, religiosity in Poland becomes a strong anti-democratic attitude.

The pro-democracy orientation is indirectly negatively affected by authoritarianism, which - as the author presents - is a permanent and almost universal feature in Polish society, which probably results from historical and cultural features. The same is true in the case of unreal thinking, which seems to be appropriate for the Polish mentality, and which also negatively affects the pro-democratic orientation. Here again arise the question of what chances can Polish democracy have with such a high intensity of its negative correlates. Indeed, according to the author, democracy seems to be under threat, but its fate does not seem to be unequivocally sealed.

Psychology of Democracy. Sketches is a book that is extremely interesting in the context of the model being explained, but also outside of it. It presents an analysis of changes in the quality of Polish democracy over the years, as well as linking them with the ruling party at the time. I find the book extremely up-to-date also in the light of recent events that took place on the Polish political scene. Mass protests against the current government, which is accused of departing from the principles of democracy, as well as the conspiracy theories spread in the media related to the current epidemiological situation, can be surprisingly largely explained by the discussed book. Therefore, apart from its undoubted scientific value, it seems to be an extremely current reading.

\section{BIBLIOGRAPHY}

CBOS. 2014. Komunikat z badań: Stosunek do demokracji i jego praktyczne konsekwencje, Warszawa. Korzeniowski, K. 2020. Psychologia demokracji. Szkice, Wydawnictwo Naukowe PWN, Warszawa. Ossowski, S. 2008. Kryzys liberalnej demokracji w Polsce na tle innych państw członkowskich Unii Europejskiej, "Studia Polityczne", vol. 2, pp. 99-114. 